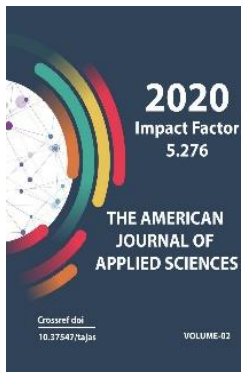

\section{The Study Of The Problem Of Life And Death In Uzbek Literature}

Khamrakulova Khurshida

Doctor Of Philological Sciences, University Of Uzbek Language And Literature Named After Alisher Navoi, Uzbekistan.
Journal Website: http://usajournalshub.c om/index,php/tajas

Copyright: Original content from this work may be used under the terms of the creative commons attributes 4.0 licence.

\title{
ABSTRACT
}

There is a growing tendency in world literature to take a new approach to works of art, to study and cover issues related to the history of word art, to study the literary text not only in the context of specific issues, but also in terms of philosophical, social and psychological issues. One such issue is the problem of life and death. Human's life, the world around him, his attitude to being is not new, but the question of human's attitude to death has been debated throughout the ages.

\section{KEYWORDS}

World literature, history of word art, terms of philosophical, social and psychological issues, problem of life and death, human's life.

\section{INTRODUCTION}

It turns out that until the idea of death was explored in a work of art, humanity's view of death had existed in one form or another since ancient times. The term "Thanatology" (the field of death) used in science as a scientific term is associated with ancient
Greek mythology. By the twentieth century, a number of disciplines had approached the subject of life and death, based on theology. Unlike other disciplines, a literary study explores the aesthetic impact of Thanatology on fiction. The study of a work of art from a 
literary-aesthetic point of view requires the study of this problem as a literary-aesthetic category. Numerous studies on life, death and its essence in world literature and philosophy, first of all, show the universal theoretical and practical significance of the subject, the study of the problem of life and death in different fields of science is the basis for the emergence of new disciplines such as Thanatology and Bioethics. Also, the fact that different interpretations of the problem of life and death, which make a special contribution to the civilization of world science and culture in the twentieth century, has a positive impact on the process of interdisciplinary integration, confirms the multifaceted nature of the problem. There is no doubt that it will serve to further update the quality of aesthetic categories. Within the category of life and death, the creative and destructive forces of human nature, its genetic and psychological roots, personality and society, human and environmental relations, the role of social relations in spiritual evolution, the presence of factors leading to suicide and patriarchy add to the topic.

During the years of independence, along with the existing scientific traditions in Uzbek literature, the principle of creative approach to new methods and approaches in world literature and their active application in research has been formed. There was a need to study the problem of life and death as a literary-aesthetic category in literature. In the study, our study of the problem not only as a linguistic concept, but also within a literary category is also due to the fact that the problem of life and death is changing, evolving, interconnected and interdependent, covering similar and different aspects of the problem.

\section{MATERIALS AND METHODS}

The existence of works in the Uzbek literature of the twentieth century on the artistic interpretation of the problem of life and death, the roots of the tragedy of the person and the expression of the pre-mortal image of man, allows a special study of the subject. In this context, the study of pure human, natural problems related to human life, destiny, personality, nature, psyche is one of the peculiarities of today's national literary process, which is illustrated by a comparison of Soviet and independence literature.

The use of death as a poetic tool in the best works of literature of the 1920 s and 1930 did not arise spontaneously. The need to define the culmination of the work, to exaggerate the social problems, often led to the deaths of the leading heroes.

\section{RESULT AND DISCUSSION}

In the literature of this period, in particular, in Hamza's "Zaharli hayot yoxud ishq qurbonlari" Maryamkhan, in Cholpon's "Kecha va kunduz" Akbarali commander, in Oybek's "Qutlug' qon" there are poisonous culminations related to the fate of Gulnor (B. Karimov). Poison was the best tool for the writer in clearly showing the pre-death state of the protagonists, in creating the unexpected. The image of the characters in the death frenzy, the artistic expression of their condition, helped to determine the writer's attitude to reality and the position he held. For example, the sharp expression of the image of Gulnor's (Oybek. "Qutlug' qon") death is marked by the difficult situation in Mirzakarimboy's house, constant nervousness, emotional trauma and aggression, while Kumush (Abdulla Qodiri. "Days Gone by") does not exceed the limit of shame. Cholpon also writes, "In the novel "Kecha va kunduz", Akbarali focuses on the psyche of the protagonist in his pre-death state. The writer said of Akbarali, "His brain 
did not understand anything, but he decided to earn at least three thousand sums by doing something tomorrow or the day after tomorrow. He would not back down from any action for that," he wrote. Even Zebi is amazed at her husband's extraordinary cruelty. That's why he stares at her, "either himself or someone else." The captain comes home drunk and is not satisfied. The poison in the holy water has a special effect on the body of the commander. If Akbarali, like Gulnor ("Qutlug' qon"), had been suffering for a long time, perhaps the situation would have been different.

But he is stunned by the unexpected news. His sudden behavior also affected his behavior: "The captain's eyes began to pop out of his pelvis. He tore his shirt and began to rub his chest and throat ... He tried to breathe with all his might. Then in a distorted voice he barely said:

"Don't strangle, don't strangle me ..." he shouted.

He took a few steps and leaned against the shelf in the wall, paused for a moment, then reached back to his throat and stretched his muscles. He punched her in the chest. He then raised one hand high and placed it on his head. There were two or three drops of tears in his eyes. Strangely, gently, calmly, and sadly, he looked at Zebi, let go of both hands, shook his head to one side, and leaned back against the wall, leaned to one side, and fell to his side. He did not move..." ("Kecha va Kunduz", p. 245).

The story of the peripetia, which began with "Shoh Edip", continues in "Kecha va kunduz". In other words, the protagonist of the work is not Sultankhan, the victim of Pasha Khan's plan, but Zebi is in trouble and exiled. Such an unexpected turn in the work ultimately determines the culmination of the work, and the reality of life is confirmed in the artistic reality.

The psychological image in Cholpon's work is perfectly expressed even in cases of death, and these images do not distort reality. Nourished by the novels of Abdullah Qodiri, Cholpon published his work. Obviously, every creative realism is drastically different from each other. Along with mastering the traditions of Cholpon, Hamza and Abdulla Qodiri, he raised the Uzbek novel to a new level of development. In "Kecha va kunduz" played not only the socio-educational essence of the events, but also the literary heroes, the processes that take place in their psyche. This is the most important contribution of Cholpon to the development of Uzbek romance.

Nevertheless, the interpretation of death in Cholpon's interpretation was somewhat classified. Because by this time, fiction had fallen into the hands of ideology, and the influence of this was felt in the works of poets and writers. Therefore, the death of Akbarali was interpreted as a punishment according to his deeds. But Cholpon Razzaq remained true to realism in completing the fate of the Sufi and Qurvanbibi.

Attitudes toward Jadid literature, a drastic change in the system, led to the renewal of certain thinking in Soviet-era literature. Although Abdullah Qahhor's 1940 novel "Qabrdan tovush" is similar to "Qiyomat", they are essentially different. Because the atheistic spirit is strong in "Qabrdan tovush" : "If people work for each other instead of praying for you, if they put their hearts for each other, if they smoke the rites they sacrifice for you as science, the earth itself will be a paradise. There will be a paradise where you will pray for people to enter this paradise." 
Such ideas should be seen as the writer's agreement with ideology. In Soviet-era prose, the spiritual existence of man was overlooked. For example, in G. Ghulam's story "Hasan Kayfiy" the main emphasis was placed on "his own mind and labor" and not on the judgment of God for man, which was a reflection of Soviet policy in fiction. This can be seen in the story "Afandi o'Imaydigan bo'ldi". Of course, this type of interpretation should be considered as the influence of the politics of the period on the work of a particular writer. Life after death is almost not described in the Uzbek literature of the XX century. Even in their possessions, it was not the religious-vital reality, but the fantasies of the writers that prevailed. Perhaps the story of "Qabrdan tovush" is the product of this fantasy. But why satire the questions and answers of the Hereafter? We can find a partial answer to this in the author's story "O'tmishdan ertaklar". The horrific scenes and sufferings of the writer's childhood may have changed his perception of God in the young Qahhor. The author's story "Qabrdan tovush" is influenced by these views. The question arises: was it necessary to materialize God to show the problem? Of course, it was not surprising that literature and the principle that the writer assumed at the time, which became a means of illuminating social problems rather than the world of emotions, portrayed reality in this way.

\section{DISCUSSION}

The problem of life and death continued in its original form in the early twentieth century, as evidenced by the work of Fitrat, Cholpon. The artistic interpretation of this problem has reached a special stage in the Soviet reality, in particular, in the stories of A. Qahhor. The size of the genre also plays a key role in the description of the problem of life and death. If in the novel the fate of the person, the problem of life and death is seriously analyzed on a large epic scale; such a situation is not observed in the stories. But in short passages the writer seals the artistic depiction of these issues in the memory of man forever, so that the reader may be horrified by the series of events, and at times his confidence in life may increase. In some cases, a smile appears on the face. This laughter is sometimes combined with hatred. The novel "Sarob" by Abdullah Qahhor, which in the 1920 s and 1930s explored the problem of life and death in a national-Islamic way, expresses the complexities of the hero's life in difficult situations, the attitude of man to death from a socio-psychological point of view. In Qodiri's novels, the problem was interpreted in the predominance of the national-Islamic spirit in the writer's faith. Especially in the transient world, the desire of the individual to find his identity, to rise spiritually, to stand up to death in this way, to seek meaning from it, became the central issue of the writer's historical novels. The popularization of the new Uzbek literature, the expansion of the scale of problems on the basis of the requirements of social life, the rise of the heroes of Qodiri due to the Islamic faith in the nature of social problems at a time when the epics of the period are reflected in fiction. For example, in the novel "Days Gone by", the dream of Usta Alim, who appeared to Otabek as a symbol of "incarnate love", "to enter the embrace of Happiness with a bright face" was to accept death as happiness in practice. Usta Alim was able to rise above physical inclinations in the chapter on love, and his view of love was also divine. Nearly a century later, the issue of accepting death as bliss was revived in the work of Khurshid Dostmuhammad. This is the manifestation of the issue of succession in art. 
The interpretations and comments on the novel "Sarob", which have caused a lot of controversy, provide a basis for drawing some serious conclusions not only about the creative fate of the hero or writer, but also about the Uzbek literature of the twentieth century in general. The character, personality, spiritual crisis of the characters of the work was connected not only with the consequences of socio-political contradictions, but also with the innate human weaknesses in the nature of the person. During the war years, literature could not demand the experiences of individuals. After all, the psychology of war had enveloped the minds of the people. In the literature of those years, the tendency to portray the heroes of the work on two fronts the courage in direct battle and behind the war, on the labor front, began to glorify their courage. In those years, our writers created works that serve the historical theme of the most up-to-date requirements of the time. Thanks to the works of such writers as Oybek, G. Gulom, H. Olimjon, Uygun, I. Sultan, M. Shaykhzoda, M. Osim, such figures as Navoi, Muqanna, Mahmud Torobi, Jaloliddin Manguberdi rose from the depths of history and took part in the bloody revenge of the living. In the prose of this period, especially Oybek's novel "Quyosh qoraymas" stands out. The play depicts the optimistic mood of the protagonist, who faces death every minute.

In the prose of the post-war period, despite the leadership of the theory of non-conflict, the depiction of subjective experiences of life and death intensified. In this regard, the hero of Said Ahmad's "Ufq" trilogy Ikromjon and his son Tursunboy can be cited as examples. Typically, both society and the state need an optimistic mood. This is an innate quality in their mood. In this sense, many artists promote an optimistic mood based on this trait, which is necessary for society. They are also completely submissive to objective reality in revealing the character's artistic world. Nevertheless, the writer can achieve the study and animation of a variety of human characters only through in-depth artistic imagery and psychological analysis. Unfortunately, despite the fact that the creative method of Soviet literature - the rule of fair reflection of life - was written in socialist realism, the fair reflection of life was replaced by a social attitude to existence. In the works of social realism, the socio-class attitude to life and the people took the lead.

The Soviets could not be in a depressed mood. Naturally, the tragedy of the person changes the mood of the hero at his death. In contrast, the hero's death was artificially optimized and an optimistic tragedy ensued. As a result, a gallery of monophonic works has emerged, and the period itself shows that over time, such works have become intolerant of interpretations. This led to the alienation of literature and the literary hero from the life of the people and the human psyche, and, consequently, to the emergence of a new literature. This means that each reality creates its own conditions and opportunities for the literary period or process. In the prose of the $70 \mathrm{~s}$ and $80 \mathrm{~s}$, the psychological image took the lead in covering the issue of life and death. As a result, the problem evolved from social too subjective. It can be said that the period of the National Awakening in Uzbek (Jadid) literature has risen to the level of a problem of life and death, radically reforming society, renewing the education system, emphasizing the role of enlightenment in changing the political and social consciousness of society. Representatives of Jadid literature approached the problem of life and death from their own positions. The issue of life and death was interpreted as a concept of the 
struggle against enlightenment with ignorance. This, in turn, played a key role in the political professions of the Jadids. Death served as a poetic medium as a solution to the conflict and culminating situations of the work of art. The poisonous culminations in the works of art were the plot solution as well as the basis for showing the psyche and psychodynamics of the protagonist.

\section{CONCLUSION}

The atheistic policy typical of the Soviet era led artists to express their views on life and death with irony and symbols under the text, or to portray them from a purely atheistic point of view. In the prose of the twentieth century, the issue of life and death took on a profound meaning. In fiction, the depiction of a hero's death has not always emerged with creative freedom. Perhaps the triumph of ideology was manifested in the death of the hero. The reflection of death in the Uzbek literature of the Soviet period informs us, on the one hand, about the specific stage of the depiction of death, on the other hand, about the contradiction and synthesis between the creative-period-artistic trinity.

\section{REFERENCES}

1. In memory of Abdullah Qahhor's contemporaries. -Tashkent: Literature and art, 1987. - $365 \mathrm{p}$.

2. Literature. Badiiyat. Eternity (memories, poems, articles). - Tashkent: Yangi asr avlodi, 2004. - 235 p.

3. Alimasov V. Thirst for philosophy or thinking. - Tashkent: Philosophy and Law, 2007. - $278 \mathrm{p}$.

4. Alimasov V. Philosophy or the art of thinking. - Tashkent: Noshir, 2008. - 255 p.

5. Aldanov M. Suicide. Moscow: Panorama, 1993 -- 414 p.
6. Aries F. Man in the face of death. Moscow: Publishing group "Progress" "Progress-Academy", 1992. -P.528.

7. Balashov L.Ye. Life, death, immortality. Moscow: 2009 .-- 315 p.

8. Berdyaev N.A. On Suicide: A Psychological Study. Moscow: MSU Publishing House, 1992 .-- 24 p.

9. Borev Yu. About the tragic. - Moscow: Soviet writer, 1961. - 391 p.

10. Durkheim E. Suicide: A Sociological Study. - Moscow: Mysl, 1994 .- 399 p.

11. Kuhn N.A. Legends and myths of Ancient Greece. -Moscow: Narodnaya asveta, 1984. - 464 p.

12. Lavrin A. The Chronicles of Charon (Encyclopedia of Death). - Moscow: Moscow worker, 1993 .-- S. 232.

13. Melnikov D. Black L. Empire of Death. $-M$ .: Publishing house of political literature, 1989. - $413 \mathrm{p}$.

14. Boltaboev H., Mahmudov M. History of literary and aesthetic thinking. Tashkent: A classic word. 2013. - $400 \mathrm{p}$.

15. Yuldashev Q. Burning word. - Tashkent: Yangi asr avlodi, 2006. - 539 p.

16. Karim B. Almighty value. - Tashkent: People's Heritage Publishing House, 2003. - 84 p.

17. Karimov B. Literary methodology. Tashkent, Editor, 2011. - 87 p.

18. Moudi R. Life after death. -Tashkent: Mehnat, 1992. - $126 \mathrm{p}$.

19. Normatov U. The wonder of the "past days". -Tashkent: Teacher, 1996. - 79 p.

20. Normatov $U$. The miracle of the Almighty. -Tashkent: Uzbekistan, 2010. - 272 p.

21. Sharafiddinov $O$ Happiness to understand creativity. -Tashkent: Sharq, 2004. - $640 \mathrm{p}$.

22. Quronov D. Introduction to Literary Studies. - Tashkent: People's Heritage Publishing House, 2004. - 223 p. 
23. Kushjonov M., Normatov U. Secrets of mastery. - Tashkent: Fiction Publishing House, 1968. - $219 \mathrm{p}$.

24. Qoshjonov M. Sarob's past and present. Abdulla Qahhor. Sarob. - Tashkent: Sharq, 1995. - 233-238-p.

25. Oybek. Commemorative blood. Tashkent: Fiction Publishing House. 1957. -355 b.

26. Cholpon. "Night and day." Works. Volume II. - Tashkent: Literature and Art Publishing House.

27. Qahhor A. Sarob. -Tashkent - Samarkand: Uzdavnashr, 1937. - 376 p.

28. Qahhor A. Sarob. Volume YI, Volume III. Tashkent: Fiction Publishing House, 1967. - $291 \mathrm{p}$.

29. Qodiriy A. Scorpion from the altar. Tashkent: Fiction Publishing House, 1959. - 249 p .;

30. Qodiriy A. "Days Gone by. - Tashkent: 